\title{
The Mediterranean Region: "Islamic" light in the architecture of the sublime
}

\author{
M. Faleh \\ The University of Western Australia, Australia
}

\begin{abstract}
This paper traces the material and the spiritual dimensions of light in the architecture of Islam. In a Quranic chapter called "An-Nur" or the light, and in a mystical group of lines "The verse of light", God has explained how light is the essence of life on earth comparing this divine dimension to the light of heaven and earth. This metaphor clearly explains its sacred dimension confirming its importance in the architecture of Islam. The phenomenal experience of this natural element is created in the interiors of buildings, transforming them into an element that enlightens the soul and energizes the space.

Light is a timeless, dynamic, and transformative entity that shapes the configuration of space and enhances its dynamism. In the architecture of Islam, it is ingeniously transforming buildings into living entities. Its penetration and its reflection through patterns and on colours accentuates the dynamism of the interiors and calls for an exploration of the duality between light, pattern, and colour. The solid surface then becomes fluid and a myriad of patterns transforms the meaning of the architectural space. Each pattern, geometry and form is a living element inside the building. Muqarnas cells beneath domes are reflecting and refracting elements depending on light quality.

This research investigates the dimension of light in Islam and explains how this dynamic entity coexists with surfaces, patterns, and colours creating a unity within a diverse architecture. The sublime becomes architectural and its fluidity then reveals an intimate relationship between the spiritual and the material. Keywords: Islamic Architecture, light, Quran, Muqarnas, Dar Lasram, Tunis.
\end{abstract}

\section{Introduction}

The light of God, the light of the prophet, Cities of Light in Islamic Spain, the moon light of Ramadhan, and the light of Islam are several expressions denoting 
the popularity of light in Islamic culture. "Nūr" or light has had different meanings in the religion of Islam and it has remained related to several aspects of the divine as well as the mundane. Light also transcends the spiritual and unmaterialistic dimension to cover material grounds as in architecture; in the architecture of Islam light played a major role in shaping spatial configurations and shifting the dynamics of space where it is projected. The physicality and materiality of light transcends its spiritual dimension, in Islam, but completes and reflects the phenomenal experience of the universe. The architecture of Islam, as an expression of the unity of Muslims and their world view, is itself the mere reflection of the power of light and of all its mystical and physical dimension. Light is as vital to this architecture as it is to the universe and its presence is powerfully translated through courtyards, walls, corners, and architectonic details.

\section{Light in Islamic culture and theology}

\subsection{Its spiritual dimension: excerpts from the Quran}

Allah is the Light of the heavens and the earth, The parable of His Light is as if there were a niche, And within it a Lamp: The Lamp enclosed in Glass; The glass as it were a brilliant star;

Lit from a blessed Tree,

An Olive, neither of the East nor of the West, Whose oil is well-nigh luminous, though fire scarce touched it; Light upon Light!

Allah doth set forth parables for men: and Allah doth know all things. Surah 24:35 A Nur-The Light (Ali [1]).

This surah or verse of the Quran is both popular and intriguing as it calls for more interpretations throughout the years and during different eras. The mystic dimension of light and the creation of the universe are both interconnected and the God of the heaven and the earth is referred to as the light of these different worlds. The metaphor of His light transcends all dimensions and it has neither limits nor boundaries. Somehow in this verse, the word light seems to be introduced in the same context as natural elements such as trees, olives, and fire; but it also seems to be setting the scene for a sacred universe. On the mystic notion of light and the parable dimension, Abdullah Yusuf Ali explains that "embedded within certain directions concerning a refined domestic and social life, comes this glorious parable of light, which contains layer upon layer of transcendental truth about spiritual mysteries. No notes can do adequate justice to its full meaning. Volumes have been written on this subject, the most notable being Ghazali's Mishkat al Anwar" (Ali [1]).

Among the 99 names of Allah, An-Nur is mentioned in the Quran as one of the attributes of Allah. He is, indeed the light of the heavens and the earth but it is also said that all his other attributions are luminous names, as well. For 
Muslims, Allah has the power of the universe and, as a creator, He blessed humans and creation not only with the physical light but also with the light of knowledge and faith. Continuously, light seems to have a great share in Islam and an elevated dimension as part of Islamic values. Often times, An-Nur or light is used in contrast with Dhulumat or darkness emphasizing on its importance in the transition from darkness into light, and from ignorance into faith (Fatani [2]). Light seems to be a very important factor of life and a reflection of purity and soul. Within this divine cosmos, the soul of mankind is in the search of the divine, both physically and spiritually, through faith and knowledge. The latter dimensions are characteristics that humans are rewarded with to enhance the reasons and the goals behind their existence. Purity is the key term that would qualify this existential experience.

As mentioned in Surah An-nur, the glass does not necessarily shine by itself unless it is penetrated by light, thus the image of the glass was compared to a brilliant star. By correlation, the followers of Allah's words are illuminated by His light and they help to enlighten others thus enhancing humanity (Ali [1]). The Quran draws an analogy between light and the straight path of peace and guidance, cited in the following verse "by which Allah guides those who pursue His pleasure to the ways of peace and brings them out from darkness into the light, by His permission, and guides them to a straight path." (Quran Al-maidah, 5:16 [3]). The use of the Arabic verb "yokhreejoo", which means to bring out, and the verb "yahdee", meaning to guide, shows the spiritual connotation and the importance that light has as it is a central factor comparable to the straight path that leads to inner peace.

An-Nur is continuously cited in the Quran to explain the reason of the creation and the image of darkness, inferring Satan, is also contrasted with that of the right path in several instances. The clear path is constantly described as nur (Quran 1-nisāa, 4:174 [3]) and the light that was sent down is a clear illustration of the importance of this dimension in Islam as it leads to success in life and the hereafter (Quran 1-a'rāf, 7:157 [3]). The importance of light in Islam and in the Islamic belief seems to be very central to the goals of existence on earth. Its presence seems to be a perfect illustration of progress, success, and civilization. The reflection of the divine light is present in the physical world of the Muslim sphere. Architecture is a field where this serenity is reproduced through the spatial configuration of buildings, walls, and details. Light somehow is a revelation of man's creativity or achievements. It is intriguing, thus, to identify the importance of light in the architecture of Islam through different mediums.

\section{Light in the architecture of Islam}

\subsection{Its spiritual dimension}

The notion of light is as important in Islam as it is for the architecture of Islam or Islamic architecture. Ernst Grube mentions that "Islamic architecture is given to hiding its principle features behind an unrevealing exterior; it is an architecture 
that does not change its forms easily, if at all, according to functional demands, but rather tends to adapt functions to preconceived forms." (Grube and Michell [4]). Islamic architecture seems to be an architecture of the veil where the rich interiors are hidden behind a simple exterior, but how does light participate in the equation and in the dynamics of the interior?

Light seems to be one of the most dynamic elements that connects the interior of buildings such as mosques or vernacular houses with the exterior. Light is both a physical connector as well as a spiritual element that transcends its physicality to express a connection with the divine world. Through courtyards, openings, and light wells, light penetrates into the courtyard of traditional homes, mosques, and even traditional shops. It helps to add some energy to the interiors by enlightening the space and it also creates and defines the space clearly, as much as required. Despite its beautifying and illuminating characteristics, light underscores the imperfection of mankind and the infinity of God. The human being continuously generates different products for this world that become beautified by light. Without light these creative products will be relatively limited. The creation of God is timeless, while the achievement of mankind is limited in time, space, and spirit (Saphic [5]).

Simple is beautiful and simple is pure. Omer also emphasizes the notion of simplicity, sincerity, and transparency in Islam and connects it with the notion of light; to him light is simple, sincere, transparent and honest, as a human should be (Saphic [5]). Sincerity or Ikhlaas in Arabic is a fundamental principle in the Islamic belief, and there is a Surah (chapter) named "Ikhlass" in the Quran. The eternal and the absolute dimension of the creator, or Allah, explains the purity and the sincerity that Muslim believers should hold towards the one and pure creator of the heavens and the earth. Allah is described as "begot none nor begotten", as "the most Affectionate, the Merciful" (Quran Al Ikhlaas, 112:1-4 [3]). The purity of the belief, the purity of the creator, and the purity of light are images of how purity and simplicity enhance the quality and the splendor of its physical manifestation on earth, even if it remains untouched and timeless. Light is virtually inexistent even if it surrounds us. It is a physical phenomenon that reflects purity and physicality in a broader sense. These transcendental dimensions as also explained as follows:

There is nothing that symbolizes these notions better than the notion of light, just as there is nothing that symbolizes the opposites better than the notion of darkness. Surely, the life of a true believer is a simple, straightforward and a clearly defined affair, from the beginning till the end. Minimalism in form and appearances, and profundity, wisdom and luminosity in substance, meaning and purpose, it stands to reason, are synonymous with the lifestyle of a believer. A true believer, furthermore, has nothing to hide, camouflage, mystify or veil when it comes to his relationships with his Creator and with his very self and his consciousness (Saphic [5]).

Light, belief and sincerity; three major concepts that seem to be strongly interrelated in the context of defining the mystery of light but also its sacred dimension. The philosophy of light in Islam unmistakably reminds us of its importance within the built environment. Domes, light wells, walls, 
Musharrabiyyah or bow windows, courtyards, etc. are noticeable elements that enrich the spatial configuration of architecture in mosques, houses, Souqs, etc.; they also play a major role in filtering the light inside these spaces. The visitor is guided easily through the subtle and minimal space and his experience is purely of mystical nature. The streets and alleys of the Medina of Tunis, for instance, show how important light is and how the transition happens from the few shadowed and transitional spaces to the alleyways and public plazas. The structure seen in the following photo shows a Sabbat or a covered alleyway where a small space is connected to the room. The implication of light will be studied in the next section through the analysis of several architectural features of a traditional house: Dar Lasram, located in the Medina of Tunis.

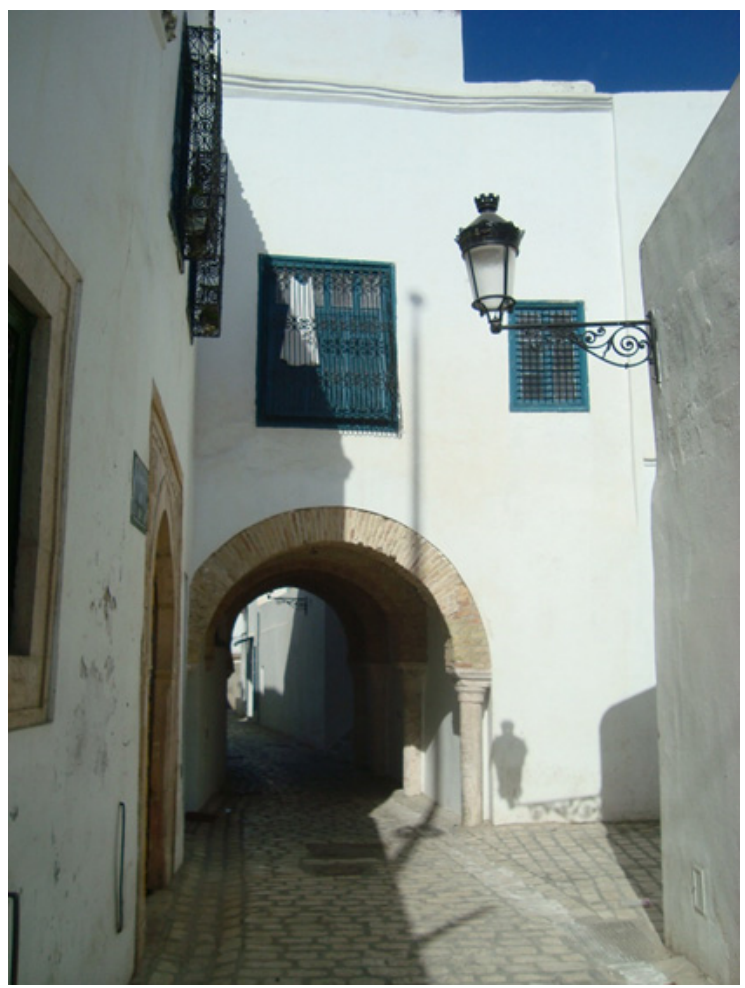

Figure 1: Covered alleyway.

\subsection{Its material dimension}

Geometry in Islamic architecture is one of the main art forms as it constitutes the heart and the foundation of its richness. As rich and complex as it is, this art form allows the light to penetrate through the different geometric shapes and to transform the shape itself into a living entity projecting it on a surface. Light can also be reflected by different geometric forms while breaking it and changing its 
direction adding a dynamic aspect to the overall composition. It is not anymore a rigid and material projection but rather a projection of a living soul. The play of reflected light enhances the dynamism of the overall structure. The case of Dar Lasram, a traditional house located in the Medina of Tunis, will be analyzed to determine how architecture and light established a dialogue under the roof of this vernacular structure. Through surface, pattern, and colour, the potentialities of light in the context of Islamic architecture will be revealed.

\section{Surface, pattern, and colour}

To build a palace worthy of his rank, he chose a neighbourhood on the fringe of Houmet Dar el bacha, which at the time was densely urbanized. Since the middle of the XIVth century, it contained the palace and the medresa, work of the powerful Hafsid minister Ibn Tafrajene, the ruins of which can still be seen today (Binous and Jabeur [6]).

That is how the story begins and how the building of this house took place in a very dense and central area of the traditional Medina of Tunis. As dynamic as it seems to be, given its several social and educational functions, light inside this house respected the needs of each of these functions as well as the transition between the inside and the outside.

\subsection{Surface and reflection}

While transitioning from the extremely elaborate entrance of Dar Lasram to the different Sqifas (or alcove), it is very diligent to notice how natural light behaves inside these spaces leading to the patio. The focus here will be mostly on the main courtyard. The courtyard, or the heart of the house as we may call it, is a very dynamic entity that plays the role of a connector but also of a regulator. It is a social connector for several activities that take place confined by the walls of the house and offering privacy to the dwellers. It is also an energy transmitter and regulator as it allows sun rays to penetrate inside the house giving the space a temporal and a spatial configuration and connecting the entire house with the sky. This connection is somehow reflective of the mystical dimension of light in such an architectural space.

The courtyard in Dar Lasram shows a rich materiality as the entire surface is embellished with materials such as marble, stucco, tiles, wood, and metal frames. In Islamic architecture, courtyards are central elements, rich with decoration, and connecting different parts of the courtyard house. It is the most favored typology of most Arab-Islamic cities to respond to the Islamic social order and the issue of privacy, to protect the house from the weather, and to regulate temperatures by storing the cool air collected during the night (Bianca [7]). Courtyards are central typologies in this type of housing and they help to shape and define the space. The hollow volume interacts with the natural light to confirm this centrality. The courtyard's symmetry is also confirmed through the solar rays that connect the courtyard to the sky and confirms the spiritual dimension connecting the material and the physical to the outside world. 


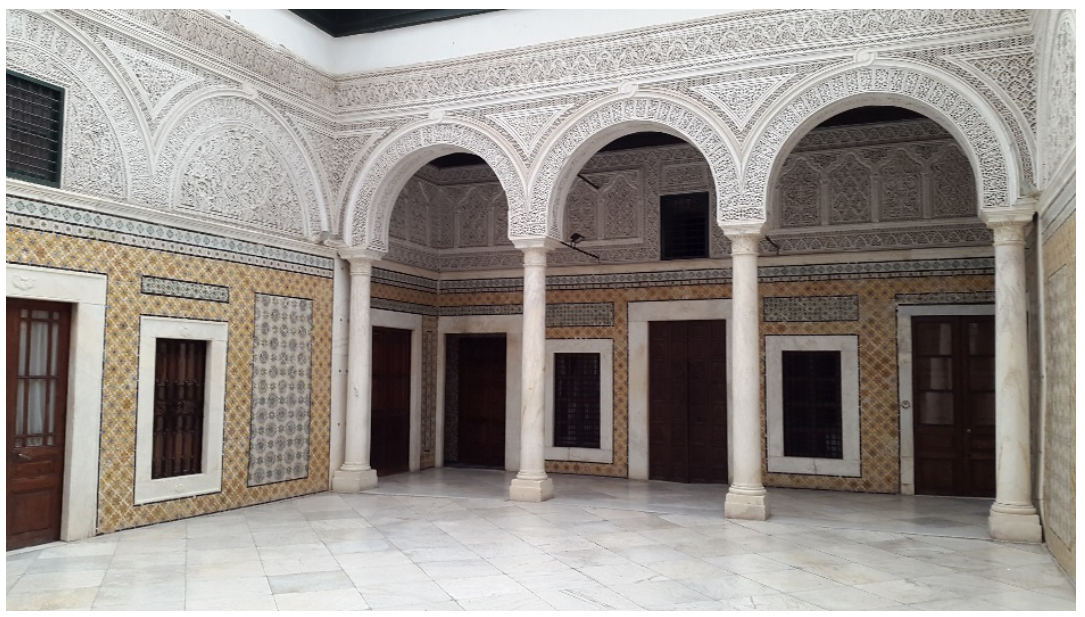

Figure 2: Courtyard Dar Lasram.

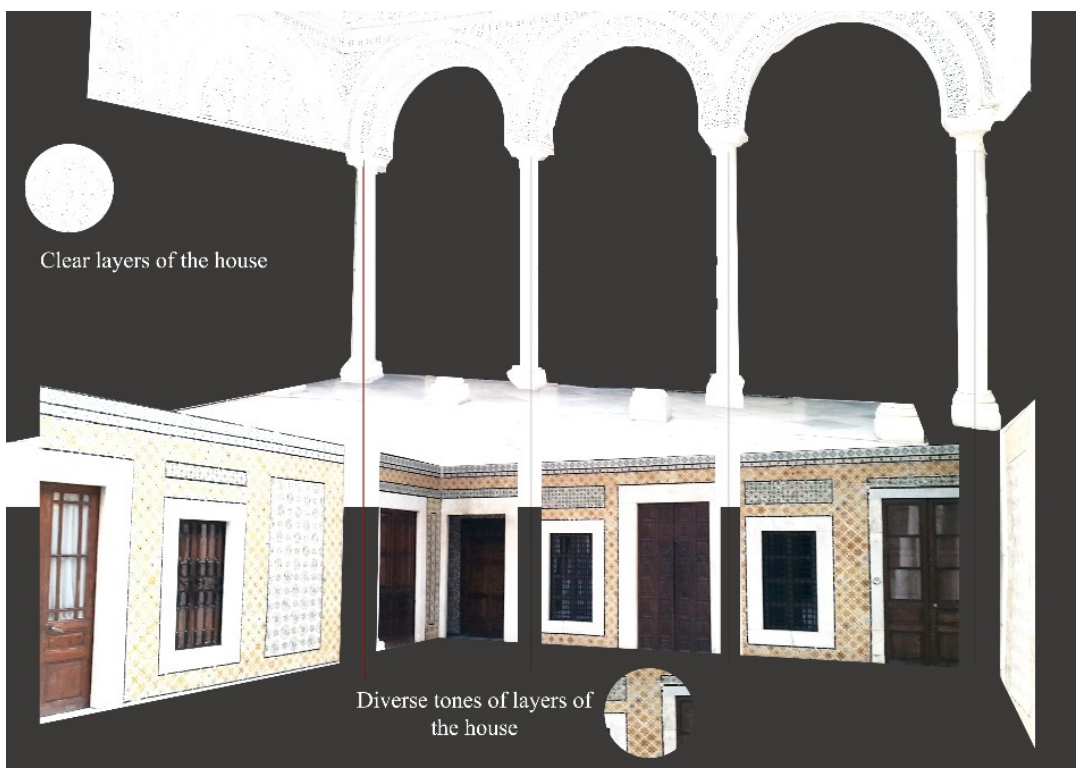

Figure 3: Light surfaces.

\subsection{Colour and reflection}

The creative use of colours in Islamic architecture enhances the character of buildings given the direct effects that colours have on people, whether materially, psychologically or spiritually (Saphic [5]). The very diverse materials inside Dar Lasram come with different tones, textures, but also colours. The white tones of stucco and marble balance the tones of this central space, and the 
coloured tones of the walls create another balance of tones. The neutrality of the white tones covering the central heart of the house is appealing and is, indeed, confirmed by the light coming from the outside.
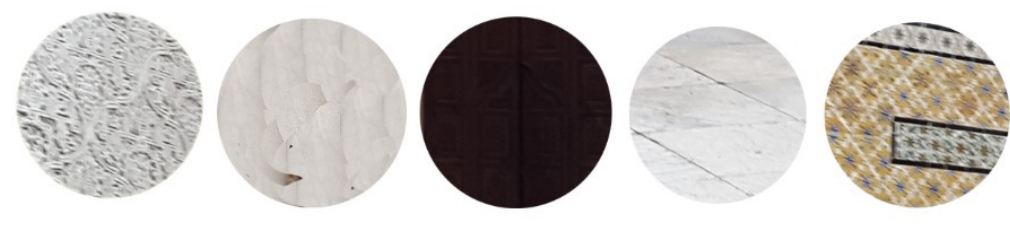

Figure 4: Variety of materials.

On a spiritual level, colours are a reflection of the creation of God on Earth and its perfection dimension. The built environment in the Islamic context is, indeed, a revelation of man's creation on earth and his mission through architecture, among other things. The diversity of the tones of tiles, for instance, explains how important colours are in creating an ensemble of tones matched together to create a palette of lights. Each colour of the traditional ceramic tilework in the courtyard of Dar Lasram obeys to certain rules as "tilers learnt to juggle with the diversity of motifs in the most ingenious manner" (Binous and Jabeur [6]). Light also comes from the colours themselves adding another interpretation to its original transparent feature. The orange and blue tiles called Afset Essid, or lion's paw, dominates the surface facing the entrance to the courtyard and somehow contrasting two tones, one with its warmth and the other one with its cold tone. As this tile dominates the surface, it "leaves little room for the white background" (Binous and Jabeur [6]), thus creating a new system of balance between the coloured tones and the natural light. Light continues to confirm the white tones.

\section{Muqarnas as a case study in the architecture of the Mediterranean}

\subsection{The architectural dimension of Muqarnas}

Besides the study of light on surface, one might question if Islamic architecture developed its designs based on more volumetric shapes and how these react with the interaction of light. Muqarnas has been known as a complex geometric form that adorns corners and structures in Islamic architecture. It is a three dimensional form that adorns different places inside a building. These elements or structures fall under the art of geometry that enhanced the architectural creativity in the context of Islamic architecture. Even though Islamic architecture focused on plane surfaces, muqarnas came as a three dimensional element or geometric patterns to connect between architecture and ornament (Bianca [7]). This decoration item comes indeed to help transition from a surface or volume to another. It decorates domes, niches, and it also remind us of the image of 


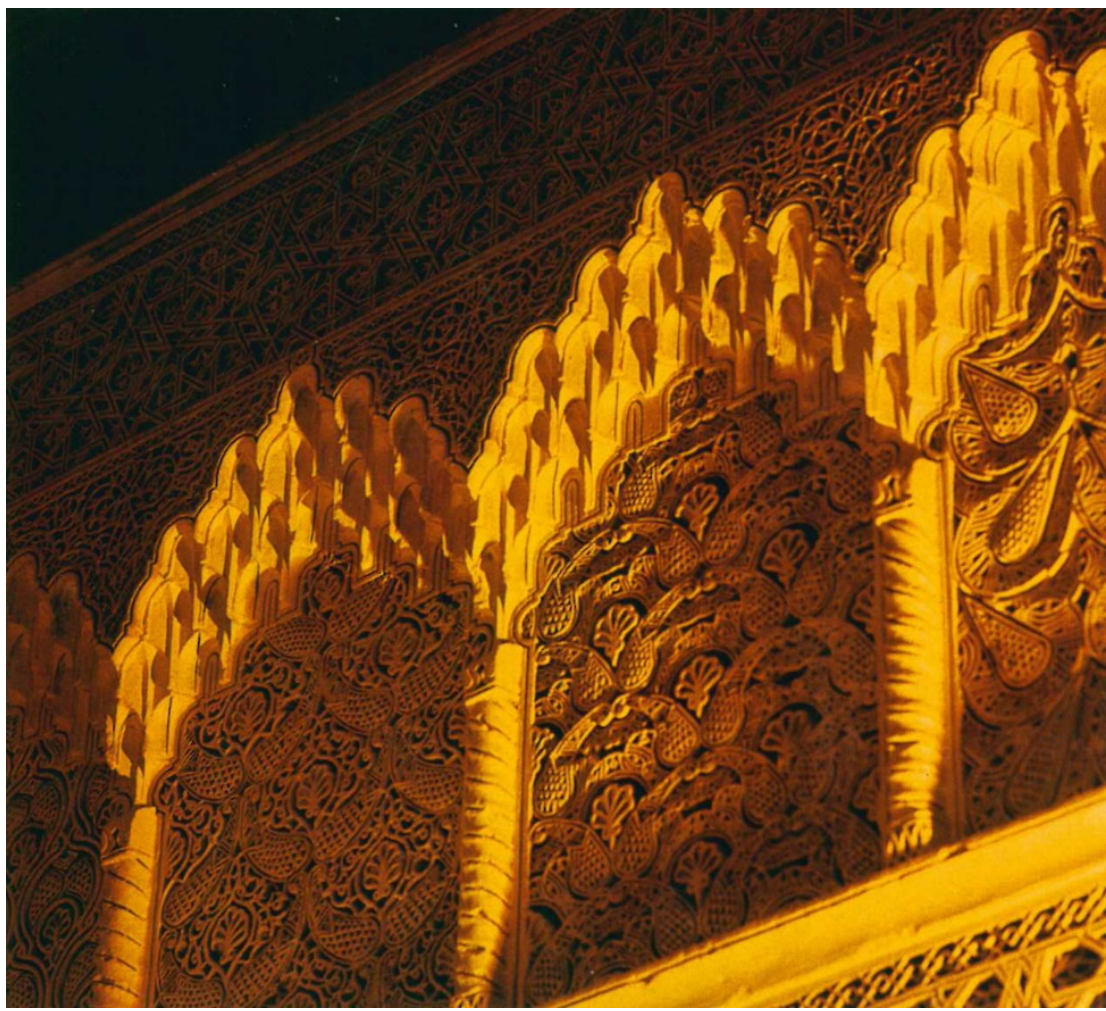

Figure 5: Detail of the Muqarnas.

stalactites inside caves. So how does Muqarnas react to light and what are its potentials? To explain the complexity of these elements, one might need to look at its properties and how it is decorated as in the following definition:

All these muqarnas domes share some basic features: (1) they are made of small distinct cells; (2) their squinches, colonnettes, and other structural features are obscured; (3) layers of stucco, paint, or glazed tiles are often used to embellish the cells, and (4) windows are used frequently, though of course in a double-shell design they are only possible at the base of the dome (Tabbaa [8]).

The complexity of these elements comes from their different architectonic structure as well as materials such as stucco and paint. Each component of the overall structure has a specific shape and a specific surface, and thus their reaction to the light follows these properties. As a detailed element, the play of shadows and lights becomes more intense and the dark surfaces contrast with the clear one creating a gradual change of ochre and yellowish tones. Light as described before creates a dynamism that transcends the plain and flat surfaces of one dimensional surfaces. The existing small holes that define stucco work also enhance the contrast of light and depth. But how does it interact with light? 


\subsection{Interaction between Muqarnas and light}

As observed in some spots of Dar Lasram and other structures of domes in Mosques, muqarnas is a complex unity within the complexity. Bianca explains that the muqarnas creates an interesting interplay between ascending and descending forms reflecting a transition that participates in creating this complexity (Bianca [7]). As the different geometric shapes are brought together, the scale of the element is somehow blurred and so is the light. The reflection of light on these elements adds a living element to the materiality of this complexity and creates a play that blurs the perception of the material and the spiritual. $\mathrm{He}$ also explains that these elements are a metaphor of the process of creation as they unfold in a gradual way and as the forms are generated from basic to more complex ones (Bianca [7]). Somehow it is a reflection on the nature of creation where elements added to other elements constitute the natural environment surrounding us. These structures come from an Islamic decorative background and transcend the decorative aspect to reveal higher levels of a hidden spirituality, where these elements become transparent. Light remains the connector as it confirms that complexity of the shape, sometimes hiding it and some other times revealing it depending on the angle.

\section{Conclusion: the architecture of the sublime}

Islamic architecture and the art that came with it played an important role in reflecting the spiritual dimension of the Muslim life in the Muslim city or space. Light, as a reflection of the divine into the material space, has revealed the hidden spirituality as it enhanced the physical qualities in the space. Light also dematerialized the different surfaces that constitute the space of the house and simplified the complexity of its forms and shapes. As interactive and dynamic as it can be, light has simplified this complexity by creating a much more clear distinction of the spatial configuration. Colour, pattern, and surface have also interacted to create a dynamism that reveals a clear and a simple space.

\section{References}

[1] Ali, A.Y. The Holy Qur'an, [S.1.]: Presidency of Islamic Researches, p. 876, 1980.

[2] Fatani, A.H. "NUR", The Qur'an: An Encyclopedia, Taylor \& Francis, p. 467, 2006.

[3] Quran English translation, www.quran.com

[4] Grube, E.J., and Michell, G. Architecture of the Islamic World: Its History and Social Meaning, New York: Morrow, pp. 12-13, 1978.

[5] Saphic, O. Colour and Light in Islamic Architecture, Muslim Tribune Online, 2011.

[6] Binous, J., and Jabeur, S. Houses of the Medina: Tunis, Tunis: Dar Ashraf Editions, p. 114, 2002. 
[7] Bianca, S. Urban Form in the Arab World: Past and Present, London: Thames \& Hudson, p. 45, 2000.

[8] Tabbaa, Y. The Muqarnas Dome: Its Origin and Meaning, Muqarnas, 3, pp. 61-74, 1985. 